\title{
ОСОБЛИВОСТІ ЕМОЦІЙНОСТІ НЕПОВНОЛІТНІХ ЗАСУДЖЕНИХ
}

\begin{abstract}
У статті досліджено порушення емоційної срери підлітків з делінквентною поведінкою. Порушення емоційно-афрективної сфрери визначаються як один із значущих фракторів, що впливає на фрормування асоціальної поведінки підростаючої особистості. Наведено огляд існуючих досліджень проблеми емоційності взагалі та проаналізовано зміст емоційності у підлітковому віці зокрема. Підкреслена наявність неоднозначного зв'язку типу емоційності з індивідуально-психологічними властивостями особистості, такими наприклад, як акцентуації характеру. Представлено результати вивчення особливостей проявів емоційності у неповнолітніх засуджених та у підлітків з нормативною поведінкою. Виявлено значущі відмінності емоційного реагування в ситуаціях, пов'язаних з інтелектуальною та комунікативною сфрерами. Неповнолітні засуджені відрізняються меншою чутливістю щодо розбіжності між очікуваним і реальним результатом дії при виконанні інтелектуальних завдань, більш слабким емоційним реагуванням на невдачі, що пов'язані з інтелектуальною діяльністю. Разом з цим, ці досліджувані характеризуються істотно більшим відчуттям занепокоєння у ситуації соціальної взаємодії, більшою чутливістю до невдач у спілкуванні, невпевненістю й роздратованістю у міжособистісних стосунках. Також встановлено, що як підліткам з нормативною поведінкою, так і неповнолітнім засудженим, притаманною є середня вираженість емоційної чутливості до розбіжностей між задуманою моторною дією і реальним результатом цієї дії. Подолання емоційних проблем у ситуаціях соціальної взаємодії запропоновано шукати у напрямку розвитку здібностей соціального та емоційного інтелекту. Це можуть бути здібності до психологічної прозорливості, антиципації у сфері міжособистісних стосунків, соціальної сензитивності й емпатії, тенденції до фоормування адекватної самооцінки, здатності до самопізнання тощо. Розглянуто параметр емоційності особистості як один з фракторів, який регулює діяльність, виступає вихідним рівнем реагування на емоціогенну ситуацію та характеризує ставлення індивіда до явищ навколишнього світу. Зроблено висновок, що саме через дослідження цього параметру можна отримати дані, які допоможуть суб'єктам соціально виховної роботи ефрективно здійснювати профрілактичну та психокорекційну роботу, спрямовану на ресоціалізацію особистості неповнолітніх засуджених.
\end{abstract}

Ключові слова: емоційність,психомоторна емоційність, інтелектуальна емоційність, комунікативна емоційність, неповнолітні засуджені, підлітки з нормативною поведінкою, емоційний інтелект, соціальний інтелект.

Постановка проблеми. Щорічно в Україні за безпосередньою ініціативою та участю неповнолітніх здійснюється більше ніж 40 тисяч протиправних дій, що становить 8,8 відсотків від загальної кількості злочинів, які зареєстровані в державі загалом. Серед цих злочинів такі як убивства, важкі тілесні ушкодження, розбійні напади, пограбування, крадіжки тощо. Основними рисами злочинності неповнолітніх стали: дитяча жорстокість, крадіжки, пограбування, розбійні напади, вимагання; залежність (наркоманія, пияцтво, проституція, тютюнопаління тощо) [4, с. 338]. Одним із значущих фракторів, який впливає на формування асоціальної поведінки підростаючої особистості, вчені називають порушення емоційно - афективної сфрери.

Аналіз причин вчинків, скоєних підлітками делінквентами, як зазначає Е.Р. Чернобродов, свідчить про те, що вони були скоєні у стані афекту або близькому до нього [9, с.91]. У дітей і підлітків не напрацьовані вміння і здібності цілеспрямовано керувати своїми вчинками, а інколи вони не мають «...бажання вийти в мотиваційному відображенні дійсності за вузькі межі ситуації» [9, с.91].

Пусковим механізмом афективних деліктів слугують афективні порушення діяльності, що призводить до звуження свідомості, порушення інтелектуально-вольового самоконтролю поведінки, супроводжується важкими агресивними діями, спрямованими зазвичай проти осіб, які стали джерелом психотравмуючих переживань. Емоційне збудження руйнує основні види самоконтролю і опосередкованості поведінки, знімає заборону на деструктивні, насильницькі дії і спонукає до них. Афеективні розлади відносяться до числа найбільш розповсюджених психічних порушень у дітей і підлітків [9, с.91].

3 цієї точки зору вивчення впливу порушень емоційної сфери неповнолітніх засуджених може допомогти знайти ефективні шляхи й методи 
роботи психологів пенітенціарних служб у подоланні проявів протиправної поведінки серед неповнолітніх. Одним з параметрів, який виявляє якісні характеристики емоційної сфери є емоційність.

Таким чином, мета нашого дослідження полягає у вивченні емоційності неповнолітніх засуджених, зміст якої може допомогти в подальшому визначити напрямок профрілактичної та психокорекційної роботи з такими підлітками.

Виклад основного матеріалу. Підлітковий вік - це складний та суперечливий період становлення особистості, який супроводжується якісними і кількісними змінами в психосексуальній, інтелектуальній та соціальній сфрерах [1, с.7]. Підґрунтям змін підліткового віку вважається біологічна перебудова організму в цілому. На поведінковому рівні це виявляється в емоційній нестійкості, некерованості, знижені працездатності і адаптаційних можливостей під час навчальної діяльності [2, с. 76]. Підлітковому віку притаманним $є$ так званий «підлітковий комплекс» емоційності, який демонструє зміни настрою підлітків - часом від нестриманих веселощів до смутку і навпаки, а також низка інших полярних якостей, які виявляються по черзі одна за одною [1, с. 227].

Не дивлячись на те, що в психологічній науці існує чимало робіт, в яких розглянуті різні аспекти емоційної сфрери підлітка (А.О. Реан, А.М. Прихожан, І.В. Дубровина, В. С. Мухіна, А. Є. Лічко, І. С. Кон та ін..) налічується обмежена кількість досліджень, де б вивчалися індивідуально-психологічні особливості його емоційності. Проте існують поодинокі спроби дослідити взаємозв'язок емоційності з іншими конструктами, що впливають на десоціалізацію особистості неповнолітного, наприклад - 3 акцентуаціями характеру. Так, у своїй роботі І.Г.Кошлань дійшла наступних висновків: в підлітковому віці емоційність виявляється у стійкій схильності до переживань емоцій певної якості (знаку, модальності), комбінація яких характеризує тип емоційності підлітка (емоційну диспозицію); підлітки з різною емоційною диспозицією характеризуються певним специфічним поєднанням індивідуально-психологічних властивостей особистості (за Р. Кетеллом). 3 одного боку, до групи підлітків з одним і тим самим типом емоційності увійшли представники з різними акцентуаціями характеру, з іншого боку, одні й ті ж акцентуації характеру властиві представникам різних типів емоційності (це пояснюється тим, що різні типи акцентуацій характеру поєднуються в одну групу завдяки наявності у них одних і тих самих емоційних рис, що виражають ставлення до світу, яке закладено в емоції кожної модальності) $[5$, c. 224].

Теоретичному обґрунтуванню феномену емоційності присвятили свої роботи Б.М.Теплов, В.Д. Небиліцин, А.Ю. Ольшаннікова та ін.
Узагальнення і подальший розвиток теорії емоційності здійснила О.П.Саннікова, яка показала, що емоційність виконує роль системоутворюючого фрактора відносно індивідуальної структури рис особистості й фрактора, що регулює діяльність [8]. Під керівництвом О.П. Саннікової також проведені диференційно-психологічні дослідження, що виявили зв'язки якісних властивостей емоційності (модальність і знак домінуючих емоцій) з різними особливостями особистості (Р.В. Бєлоусова, І.В. Бринза, І.А. Василенко, О.А. Кисельова, І.Г. Кошлань, О.В. Кузнєцова, О.А. Орищенко, А.В. Сергєєва та ін.).

Емоційність характеризує зміст, якість і динаміку емоцій. Змістовий аспект емоційності відображає явища i ситуації, що мають особливе значення для людини. Якісні властивості, які $€$ найважливішими характеристиками емоційності, характеризують ставлення індивіда до явищ навколишнього світу і мають своє відображення в знаках та модальності домінуючих емоцій [2, с.99].

Емоційність як стійка властивість індивідуальності, у співвідношенні із іншими емоційними явищами виступає як вихідний рівень реагування на емоціогенні ситуації. Вочевидь саме відмінностями емоційності як стійкої властивості індивідуальності можна пояснити різні за якістю, за інтенсивністю актуальні емоції, що виникають у різних людей в одних і тих самих ситуаціях [2, с.99-100].

Отже, розглядаючи параметр емоційності особистості як один з факторів, який регулює діяльність, виступає вихідним рівнем реагування на емоціогенну ситуацію, характеризує ставлення індивіда до явищ навколишнього світу можемо припустити, що через дослідження цього параметру можна отримати дані, які допоможуть суб'єктам соціально виховної роботи ефективно здійснювати профрілактичну та психокорекційну роботу спрямовану на ресоціалізацію особистості неповнолітніх засуджених.

У своєму дослідженні в якості психодіагностичного інструменту нами було застосовано блок «Емоційність» опитувальника формально-динамічних властивостей індивідуальності В. Русалова [7], що дозволило виміряти три види прояву емоційності: психомоторну, комунікативну, інтелектуальну.

Для статистичної обробки результатів було використано t-критерій Стьюдента для незалежних вибірок.

Результати, наведені у таблиці 1, свідчать про те, що за шкалою «Інтелектуальна емоційність» показник у групі підлітків з нормативною поведінкою вірогідно перевищують показники за означеною шкалою у групі неповнолітніх засуджених $(\mathrm{p} \leq 0,001)$.

За шкалою «Комунікативна емоційність», навпаки, у групі неповнолітніх засуджених зафрік- 
Показники емоційності неповнолітніх засуджених та піділітків з нормативною поведінкою $(\mathrm{M} \pm \mathrm{m})$

\begin{tabular}{|c|c|c|c|c|}
\hline Шкали & 1 група & 2 група & t & p \\
\hline Психомоторна емоційність & $28,11 \pm 0,71$ & $30,02 \pm 1,07$ & 1,49 & - \\
\hline Інтелектуальна емоційність & $23,73 \pm 0,48$ & $28,46 \pm 0,98$ & 4,33 & 0,001 \\
\hline Комунікативна емоційність & $35,64 \pm 0,52$ & $29,22 \pm 1,09$ & 5,32 & 0,001 \\
\hline
\end{tabular}

совано вірогідно більший показник порівняно з підлітками з нормативною поведінкою ( $p \leq 0,001)$.

Отже, неповнолітні засуджені відрізняються меншою чутливістю щодо розбіжності між очікуваним і реальним результатом дії при виконанні інтелектуальних завдань, більш слабким емоційним реагуванням на невдачі, що пов'язані з інтелектуальною діяльністю.

Разом з цим, ці досліджувані характеризуються істотно більшим відчуттям занепокоєння у ситуації соціальної взаємодії, більшою чутливістю до невдач у спілкуванні, невпевненістю й роздратованістю у міжособистісніх стосунках. Спілкування, це те, чого надто потребують неповнолітні засуджені, як зазначає один з психологів виправної колонії [10].

3 урахуванням результатів дослідження, можемо припустити, що неповнолітні засуджені не володіють здатністю гармонізації взаємин та вмінням вирішувати міжособистісні конфлікти.

За шкалою «Психомоторна емоційність» вірогідні відмінності між першою та другою групами встановлені не були. 3 урахуванням довірчих інтервалів показники обох груп можуть бути віднесені до середнього рівня. Це свідчить про те, що як підліткам з нормативною поведінкою, так і неповнолітнім засудженим, притаманною $€$ середня вираженість емоційної чутливості до розбіжностей між задуманою моторною дією і реальним результатом цієї дії.

Подолання емоційних проблем у ситуаціях соціальної взаємодії науковці пов'язують з розвитком здібностей соціального та емоційного інтелекту (Д. Гілфорд, Д. Гоулман, Д. Майер, П. Саловей, Р. Бар-Он, І. Андреєва, О. Власова, Е. Носенко, Д. Люсин). До речі, співвідношення і міра перетину цих понять розуміється різними дослідниками по-різному. Деякі автори, наприклад, бачать зону перетину цих двох феноменів у психологічній прозорливості, антиципації у сфері міжособистісних стосунків, соціальній сензитивності й емпатії, тенденції до формування адекватної самооцінки, здатності до самопізнання [6, с.245].

Таким чином, ми вважаємо, що емоційні проблеми неповнолітніх засуджених, які виникають у ситуаціях спілкування, ймовірно можна долати шляхом розвитку здібностей соціального й емоційного інтелекту.
3 урахуванням того фракту, що, як показали результати нашого дослідження, неповнолітніх засуджених мало бентежать невдачі, пов'язані з інтелектуальною діяльністю, відтак - це також може бути зоною роботи та пильної уваги фахівців, які здійснюють профілактичну та психокорекційну роботу з даними особами.

\section{Література:}

1. Абрамова, Г. С. Возрастная психология: Учебное пособие для студентов вузов. - М. Академический проект; Екатеринбург: Деловая книга, 2000. 624 с

2. Бабчук О.Г. Специфіка співвідношення показників толерантносі та емоційності. Наука і освіта. 2014. С.99-103.

3. Дубровина, И. В. Формирование личности в переходный период от подросткового к юношескому возрасту. - М.: Педагогика, 1987. $121 \mathrm{c}$.

4. Карпюк Ю.А. Фрустрація як детермінанта асоціальної поведінки сучасних підлітків. Науковий вісник Херсонського державного університету. 2019. Вип..1. с. 338-343

5. Кошлань И.Г. Психологические особенности эмоциональности подростков и стили семейного воспитания. Дис. канд.психол. наук. Одесса, 2005. 243c.

6. Милославська О.В. Особливості взаємозв'язку емоційного інтелекту та соціального інтелекту. Вісник Національного університету оборони України, № 5 (30). 2012. С. 240-245.

7. Русалов В.М. Опросник формально-динамических свойств индивидуальности. М., 1997. 68c.

8. Саннікова О. П. Континуально-ієрархічна модель емоційності. Наука $і$ освіма. 2014. № 1. С. 44-50.

9. Чернобродов Е.Р. Влияние эмоциональных состояний на мотивацию делинквентного поведения несовершеннолетних. Психопедагогика в правоохранительных органах, 2006, №2(26). C.89-92.

10.Шаповалова М.Г. Психолого-педагогічна характеристика вихованців Курязької виховної колонії ім.. А.С. Макаренка. Вестник ассоциации психиатров Украині. №5,20013_ mif_ua.com/ archive/article/37544 
Pryimachenko O. M. Study of emotionality in juvenile convicts

The emotional disorders of adolescents with delinquent behavior are briefly discussed in the article. Disorders of the emotional-affective sphere are defined as one of the significant factors influencing the formation of antisocial behavior of the growing personality. A brief overview of existing research on the problem of emotionality in general is made and the content of emotionality in adolescence in particular is analyzed. The presence of an ambiguous connection between type of emotionality and individual psychological properties of personality, such as accentuations of temper, is emphasized. The results of study of emotionality manifestations in juvenile convicts and adolescents with normative behavior are presented. Significant differences in emotional response were found in intellectual and communicative situations. Juvenile convicts are less sensitive to the discrepancy between the expected and actual outcome of intellectual tasks, and have a weaker emotional response to failures relayed to intellectual activity. At the same time, these persons are characterized by a significantly greater sense of anxiety in the situation of social interaction, greater sensitivity to failures in communication, uncertainty and irritability in interpersonal relationships. It was also found that adolescents with normative behavior, as well as juvenile convicts, are characterized by an average expression of emotional sensitivity to the differences between the intended moving action and the actual result of this action. It is suggested to search overcoming of emotional problems in situations of social interaction in the direction of developing the abilities of social and emotional intelligence. These may be the ability to psychological clairvoyance, anticipation in the field of interpersonal relationships, social sensitivity and empathy, the tendency to form adequate selfesteem, the ability to self-understanding and so on. Considering the parameter of emotionality as one of the factors that regulates activity, acts as the initial level of response to emotional situation, characterizes the individual's attitude to the world, it is suggested that through studying emotionality data can be received that help specialists to carry out preventive and psycho-correctional work aimed at resocialization of juvenile convicts.

Key words: emotionality, psychomotor emotionality, intellectual emotionality, communicative emotionality, juvenile convicts, adolescents with normative behavior, emotional intelligence, social intelligence. 